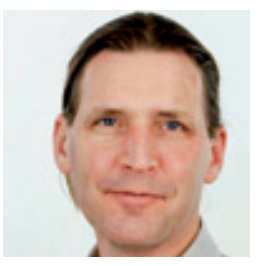

\section{Erik Oftedal}

Direktør Analyse og strategi

Arbeids-og velferdsdirektoratet

Foto: NAV/Thomas Bjørnflaten

\title{
Syk nok til å jobbe?
}

\section{I den norske IA-prosessen har myn- dighetene og partene i fellesskap prøvd å tildele de involverte aktørene tydelige forpliktelser i sykefraværs- arbeidet. Men spørsmålet er om ikke bare roller, men også tradisjonelle tenke- og arbeidsmåter, må endres for at vi skal klare å gjøre noe som virkelig monner. Det gjelder antakelig også legene.}

Legestanden har alltid hatt et noe ambivalent forhold til sykefraværsarbeidet. Mye kan knyttes til mange roller eller hatter: Man er en fagperson som profesjonelt skal helbrede, men også en portvakt som skal kunne nekte tilgang til samfunnets inntektssikringsordninger. Og som om det ikke er nok, så glir man også lett inn i en advokatrolle når det gjelder andre instanser pasienten må forholde seg til.

I tillegg innebærer sykefraværsarbeidet at legen må forholde seg til noe annet og mer enn sykdom: Her er forholdet mellom sykdommen/lidelsen og omgivelsenes/ arbeidsplassens krav og forventninger det interessante. Disse kravene og forventningene er, enten det er på en konkret arbeidsplass eller i arbeidslivet generelt, ikke noe en lege nødvendigvis er ekspert på.

Oppdraget til legestanden er dermed utfordrende og til og med motsetningsfylt. Og det blir neppe enklere når mange - bl.a. den ekspertgruppen regjeringen hadde $i$ arbeid sist vinter - har satt en del fundamentale spørsmålstegn ved det som kanskje er en tradisjonell tilnærming til sykefravær:
Det første angår synet på sykdom. Storparten av sykmeldte har problemer som kan være vanskelige å diagnostisere, der et sykdomsbegrep som er både omskiftelig og rundt i kantene, kan være vanskelig å anvende. Demarkasjonslinjen mellom syk og ikke-syk er ikke åpenbar. Verden er ikke enten/eller, men like mye både/og.

For det andre la nevnte ekspertutvalg vekt på at arbeid også måtte betraktes som et redskap i den medisinske verktøykassa: Arbeid kan virke terapeutisk - det kan være et helt vesentlig element $\mathrm{i}$ den medisinske behandlingen. En stor internasjonal forskningslitteratur viser at for alle utenom et veldig lite mindretall, er det helsefremmende å jobbe. Forskningen viser også at for de som allerede har et helseproblem, virker arbeid stort sett positivt ikke bare i forhold til inntekt, livskvalitet og en rekke andre ting, men også når det gjelder den medisinske siden av saken.

For det tredje vet vi at a) en svært stor andel av oss bærer med oss en eller annen diagnose eller lidelse, og b) at langt de fleste i arbeidsaktiv alder med sykdom eller lidelser faktisk er i arbeid, på tross av sine plager. Allerede dette antyder to ting: At flere antakelig kunne arbeide til tross for sin lidelse, og ikke minst at langt flere i alle fall kan jobbe noe, dvs. så mye de makter og så mye som er medisinsk forsvarlig. Det nevnte ekspertutvalget gjorde dette til sin fanesak: Så lenge arbeid ikke er ytterligere helsenedbrytende, bør tommelfingerregelen være en gradert sykmelding. Den medisinske bevisbyrden bør være tung for å forsvare totalfravær.

Det faktum at svært mange syke faktisk jobber, antyder også at dette i minst like stor grad handler om den andre delen av likningen, nemlig omgivelsenes forventninger og krav. Vi snakker om et forhold eller et misforhold. Skal vi få betydelige endringer i det norske sykefraværsnivået, vil derfor mye stå og falle på viljen og evnen til å finne løsninger på arbeidsplassene, slik at de som i det hele tatt kan, jobber det de kan. Og her skal det ikke være tvil om at NAV vil gjøre sitt for å utfordre og støtte arbeidsgiverne.

Den enkleste og mest nærliggende fallback-løsningen kan være å skrive ut en $100 \%$-sykmelding når arbeidsgiver kapitulerer - selv om det kan være mistanke om at det ikke er gjort grundige nok vurderinger på arbeidsplassen. Man sikrer i alle fall økonomien i en ellers ofte vanskelig situasjon. Men dette kan samtidig være helsemessig destruktivt for den enkelte, og det er heller ikke gunstig for samfunnsøkonomien. Mitt håp er derfor at også legestanden bidrar til å legge et tungt ansvar på aktørene på arbeidsplassen. Det er de som kan sørge for at personer som kan og bør jobbe det de kan, faktisk får anledning til dette. Når legene nå etter hvert også mottar oppfølgingsplaner fra arbeidsgiveren/arbeidstakeren, vil dette være en ny variant av advokatrollen som forhåpentligvis legene legger sjelen sin i fremover.

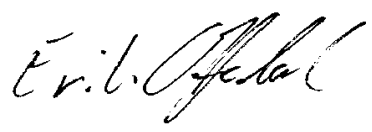

Sjokkbølgebehandling av tendinopati

Rutiner ved forskrivning av p-piller

Pasientinformasjon
Kroniske muskelsmerter

- Uførhet og sykefravær ved muskelsmerter

Slanking anno 1863 